\title{
EMERGENCE DELIRIUM IN PEDIATRIC PATIENTS UNDERGOING GENERAL ANESTHESIA
}

\author{
Greta Patapavičiūtè ${ }^{1}$, Laura Lukošienėe $\dot{e}^{2}$, Ilona Razlevič $\check{e}^{2}$, Andrius Macas ${ }^{2}$ \\ ${ }^{1}$ Department of Anesthesiology and Reanimatology, Faculty of Medicine, Vilnius University \\ ${ }^{2}$ Department of Anesthesiology, Medical Academy, Lithuanian University of Health Sciences
}

Keywords: agitation, general anesthesia, children.

\section{Summary}

Background: Emergence delirium (ED) is described as a transient state of cognitive disturbance and psychomotor agitation, which begins with emergence from anesthesia and continues through the early recovery period. The incidence of ED in the pediatric population remains unclear and ranges from 10 to $80 \%$. The pathophysiology and underlying mechanisms of ED are also uncertain. This study aimed to determine the prevalence of ED, potential risk factors that may contribute to the development of ED and observe behaviour changes related to ED in the late postoperative period. Methods: A prospective observational study was carried out with children aged 1 to 12 years. The child's behaviour before anesthesia was evaluated using the Pediatric Anesthesia Behavior (PAB) score. Medications used during the perioperative period were registered. The Watcha scale was used to evaluate if children developed ED and the Visual Analogue Scale (VAS) was used to register pain intensity during the first 15 minutes after the awakening. Parents of patients who experienced agitation were asked to assess their child's behaviour two weeks after the anesthesia. Results: Among 136 observed patients 24 (17.6\%) had ED. The duration of anesthesia among ED experienced patients was 45.42 (SD 18.35) $\mathrm{min}$ and it was significantly shorter than among children who didn't develop ED - 60 (SD 29.03) min, p = 0.016. Eighteen (15.5\%) patients in a mild pain group (VAS 0 to 3 ) experienced ED while in a moderate- 25 severe pain group (VAS 4-10) there were $6(37.5 \%)$ children who developed ED, $\mathrm{p}=0.033$. However, age, the American Society of Anesthesiologists Classification (ASA) class, surgery type, behaviour before anesthesia induction and perioperative medications were not associated with ED. Conclusions: The prevalence of ED observed during our study, short duration of anesthesia and postoperative pain association with ED coincided with the results specified by other researchers. ED associated behavior changes were reported in the late postoperative period. Our other findings appeared to be not consistent with the results reported in other studies. Thus, the dilemma of ED still remains unresolved.

\section{Introduction}

Emergence delirium (ED) is described as a transient state of cognitive disturbance (crying or moaning, incoherence) and psychomotor agitation which begins with emergence from anesthesia and continues through the early recovery period [1-3]. While the definition of ED is not unified among researchers, it is worth mentioning that while ED is specific to the early postoperative period the phenomenon itself reflects DSM-IV/DSM-5 delirium criteria.[1]. Children emerging from anesthesia often do not recognize their environment and even parents, may often be disoriented, extremely agitated and behave violently [4]. This altered state of consciousness may be caused by such risk factors as stressful induction, rapid awakening from anesthesia, airway obstruction, pre-school age, duration of anesthesia, etc. [5]. It is known that halothane was a risk factor for decades. However, this title was claimed by a newer, short-acting and common volatile anesthetic these days - sevoflurane [6-8]. Even though sevoflurane has a lot of advantages over other inhalational anesthetics, one of its properties (that is rapid emergence from anesthesia) is linked with a higher incidence of ED [9]. Another known property of sevoflurane that at high concentrations it induces seizure-like electroencephalogram recordings. Some reachers hypothesized that being long enough under deep anesthesia (bispectral index (BIS) $<45)$ might correlate with ED but they failed to find the correlation. Others found out that the PAED score was greater after deep anesthesia but it was not statistically significant [10]. A ray of other medications used perioperatively is also 
reported as agents that might be related to ED, for example, midazolam or ketamine $[11,12]$. A patient affected by ED might exhibit abnormal trashing behavior, is inconsolable, might pull out intravenous lines, injure oneself. These changes are a major source of anxiety to medical caregivers and parents because they are hard to distinguish from pain or discomfort and nursing becomes a challenge $[4,5]$. The incidence of ED in pediatric populations is still unclear and ranges from 10 to $80 \%[3,8,16]$. The pathophysiology and underlying mechanisms of ED are also uncertain. Some authors hypothesize that it might be caused by the neurotoxic effect of anesthetic agents on the developing brain as it was found in animal studies [17]. There are several diagnostic tools created to recognize this condition. The PAED and the four-point Watcha scales seem to be the most popular ones [23] There is also a five-point scale described by Cravero which is also quite common among various researchers. Cut off points are 3 and above for the Watcha scale, 4 and above for the Cravero scale while the episode of ED has to last for at least $5 \mathrm{~min}[13]$. However, researchers disagree if a cut off point for the PAED scale should be 10 or 12 . Several rating scales have been used to diagnose ED, but comparative studies have been difficult because of the lack of unification between these scales [14]. The PAED scale specifically includes an item of consolability which reflects pain [15]. Despite that ED is self-limiting and often does not require any treatment it is not innocuous. Behavioral changes such as general anxiety, night-time crying, enuresis, separation anxiety, and temper tantrums were reported in up to 50 percent of children [18]. On the other hand, the transient nature of these behavioral changes has been observed, but the question still remains if they are serious side effects of ED [19]. It is possible that ED might be confused with pain or vice versa. This may lead to either an unnecessary pharmacological treatment of a self-limiting disturbance or to an under or delayed treatment of postoperative pain which is not acceptable [20].

This prospective observational study evaluates peculiarities of emergence delirium in our hospital given that the results in many studies are not consistent or still are open for further investigation.

Our aim was to evaluate the incidence and risk factors in different age groups for this condition. As well as to determine if every case of ED needed treatment and what behaviour changes might be associated with the occurrence of this abnormal state of consciousness.

\section{Methods}

A prospective observational study was carried out with children aged 1 to 12 years in Lithuanian University of
Health Sciences, Kaunas Clinics, the department of Anesthesiology from July to November in 2018. An approval number BEC-MF-438 to conduct this research was given by Bioethics Center at Lithuanian University of Health Sciences, Kaunas, Lithuania in June 2018. Both written consent to participate in this study and to publish collected data were obtained from guardians from all parents. We have included preschool (1-6 years old) and school-aged children up to the age of 12 to have the chance to compare prevalence in these two age groups as previously seen in other studies [21]. The patients had to be relatively healthy and correspond to the I-II American Society of Anesthesiologists Classification (ASA) classes. And vice versa, exclusion criteria were III-IV ASA classes, patients who had any systemic, neurological or psychiatric illnesses as we wanted to be sure that the occurrence or evaluation of ED was not affected by any means. Infants under the age of 1 were not included as we did not find many studies including this age group in their research.

A part of our routine in the clinic is to premedicate patients if they feel very anxious prior to surgery or if the anesthesiologist thinks it is necessary. For this purpose, midazolam (0.1-0.2 $\mathrm{mg} \mathrm{p} / \mathrm{o})$, or thiopental $(30 \mathrm{mg} / \mathrm{kg} \mathrm{p} / \mathrm{r})$ is usually prescribed by the attending anesthesiologist. Most of the children were given increasing doses $(2-5 \%)$ of sevoflurane mixed with air and oxygen for induction of anesthesia and then intravenous medication followed such as fentanyl $(0.5-2 \mathrm{mcg} / \mathrm{kg})$, propofol $(2-7 \mathrm{mg} / \mathrm{kg})$ and muscle relaxants (rocuronium $(0.4-0.6 \mathrm{mg} / \mathrm{kg})$ or mivacurium $(0.2 \mathrm{mg} /$ $\mathrm{kg})$ ) if needed. Those children who were compliant with the anesthesia procedure were induced intravenously only with previously mentioned medications. All patients underwent general anesthesia and were intubated with an endotracheal tube or laryngeal mask airway was inserted. Regional anesthesia with levobupivacaine (not exceeding a dose of 2 $\mathrm{mg} / \mathrm{kg}$ ) was given if needed according to surgical procedure protocol. Anesthesia was maintained with sevoflurane and fentanyl $(0,5-1 \mathrm{mcg} / \mathrm{kg})$ boluses if needed. All children received paracetamol $15-20 \mathrm{mg} / \mathrm{kg}$ IV intraoperatively and/ or ketoprofen $(2 \mathrm{mg} / \mathrm{kg})$ to ensure post-operative analgesia. If pain persisted in the post-anesthesia care unit, then fentanyl intravenously would have been an appropriate option for pain treatment.

A child's behavior before anesthesia was evaluated by an anesthesiologist or during induction starting from the point where a patient was laying on the operating table until he/ she fell asleep under the influence of anesthetic drugs. Following the observation, an evaluation was made using the three- point observational the Pediatric Anesthesia Behavior (PAB) score which is considered simple to use in a clinical environment (Table 1). The PAB score is very reliable in 
predicting an increased risk of developing postoperative behavioral disturbance and equates to other validated scales such as the m-YPAS [12]. Medications that were used during the perioperative period were registered. No parents were present during the induction of anesthesia in the operating room. The Watcha scale was scored by the nurse caring for the child in the postanesthesia care unit at three-time point stamps at 5, 10 and 15 minutes after the surgery (Table 2). This four-point scale was chosen as it is thought that it is a simpler tool to use in clinical practice and may have a higher overall sensitivity and specificity than the PAED or the Cravero scales [24]. A cut-off score was 3 and above to consider the occurrence of ED. The Visual Analogue Scale (VAS) and the "Faces" pain rating scale were used to register pain intensity at the same time stamps alongside the Watcha scale. The measures of the "Faces" pain rating scale were later unified to match the VAS scale. The VAS scores then were divided into two groups as follows: from 0 to 3 analgesia was considered to be effective while scores from 4 to 10 meant analgesia being ineffective. This way of grouping was chosen following the logic behind Pain Ladder from World Health Organisation. A follow up was made by a trained medical student calling parents of patients who experienced agitation and they were asked to assess their child's behavior before and two weeks after the anesthesia. We created some polar questions based on the Post Hospital Behavior Questionnaire and reported abnormal behavior after the emergence of delirium in other studies. We have asked to agree or disagree with the questions. Any supplemental observations from parents were registered as well.

The data was collected using Microsoft Excel and statistical calculations were made using IBM SPSS Statistics

Table 1. The Pediatric Anesthesia Behaviour score.

\begin{tabular}{|l|l|l|}
\hline Score & \multicolumn{2}{|c|}{ Description of behaviour } \\
\hline $\mathbf{1}$ & Happy & Calm and controlled. Compliant with induction \\
\hline $\mathbf{2}$ & Sad & $\begin{array}{l}\text { Tearful and/or withdrawn but compliant with } \\
\text { induction }\end{array}$ \\
\hline $\mathbf{3}$ & Mad & $\begin{array}{l}\text { Loud vocal resistance (screaming or shouting) } \\
\text { And/or } \\
\text { Physical resistance to induction requiring physical } \\
\text { restraint by staff and/or parents }\end{array}$ \\
\hline
\end{tabular}

Table 2. The Watcha behaviour scale.

\begin{tabular}{|l|l|}
\hline Score & Description \\
\hline $\mathbf{1}$ & Calm \\
\hline $\mathbf{2}$ & Crying, but can be consoled \\
\hline $\mathbf{3}$ & Crying, cannot be consoled \\
\hline $\mathbf{4}$ & Agitated and thrashing around \\
\hline
\end{tabular}

for Windows, version 20. A sample size calculation was made using the recommendations by Charan J. et al. with the absolute error of 5\% and a type 1 error of $5 \%$ [22]. A sample size of at least 138 patients was determined with a size of $10 \%$ prevalence. Differences with $p<0.05$ were considered statistically significant. The distribution of data was evaluated using the Kolmogorov-Smirnov test. For normally distributed variables means and standard deviations were reported. Categorical variables were summarized using frequencies and percentages (\%) and compared between the groups using a chi-squared test.

\section{Results}

Overall, 148 children undergoing general, orthopedictraumatological and otorhinolaryngologic surgery were assessed for eligibility to participate in the study, with 136 meeting the study inclusion criteria (Figure 1).

Among 136 patients ED occurred in 24 (17.6\%). The mean age between participants was 5.66 (1-148 12, SD 3.15) years. No difference was found between ED occurrence and age, age groups, sex groups, surgery urgency, and surgery types as shown in Table 3.

The behavior of children was evaluated using the PAB score. We compared it with ED incidence 153 but significant differences were not observed (Table 4).

Twenty-nine $(21.3 \%)$ children were premedicated and 3 $(12.5 \%)$ of them experienced ED. There was no statistically significant relationship between ED and premedication before anesthesia $(\mathrm{X} 2(\mathrm{df}=1)=1.352 ; p=0.245)$ or $\mathrm{ED}$ and

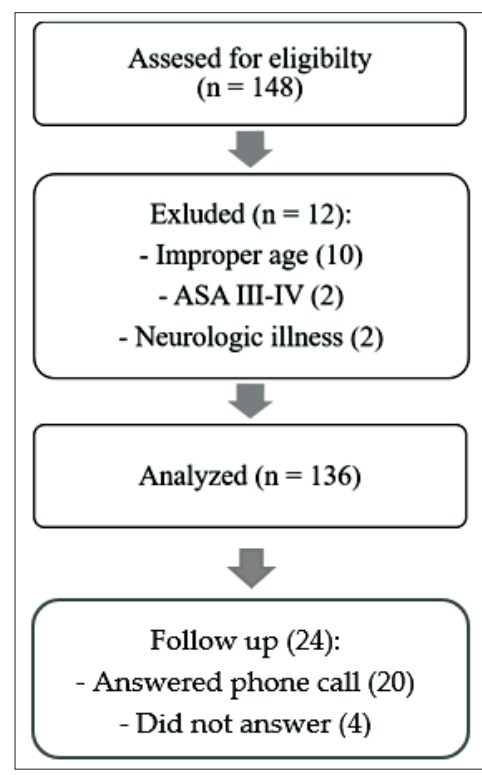

Figure 1. Patient Flow Diagram 
medications used at the later stage of anesthesia.

The average duration of anesthesia was 57 (SD 27.97) min. Shorter duration of anesthesia - 45.42 (SD 18.35) min seems to be significantly linked to ED occurrence when compared to longer duration - 60.45 (SD 29.03) $\mathrm{min}, p=0.016$.

Our study showed that pain and ED might be linked. The results are shown in Table 5.

Treatment for ED was applied to $4(16.67 \%)$ patients out of 24 cases. One patient received propofol and 3 children received fentanyl.

Two weeks after the operation we have called parents of patients who have experienced ED for a follow-up. We have managed to reach 20 out of 24 parents. Parents had to compare their child's behavior over the past 2 weeks with behavior before the anesthesia by agreeing or disagreeing with the statements listed in Table 6.

As seen in this table, it seems that the children who were affected by ED were mostly anxious, were not fond of the dark or got upset if someone mentioned hospital. Seven parents did not notice any difference at all. The mother of the monozygotic twins and the father of a boy who was in emergence delirium for over 30 minutes felt like their children's behavior did not change at all too. We asked if parents noticed anything similar to what we have asked, and one mother reported she thought that her child was daydreaming more than usual, and one child had a lower appetite than before. Any further statistical analysis on this issue was not performed due to no control group.

\section{Discussion}

The purpose of this study was to examine the possible risk factors of ED. As it is seen in our study results the incidence of ED was $17.6 \%$ while various authors report it being from 10 to $80 \%$ [16,23]. In our opinion, the results differ because of the used techniques during anesthesia, performed surgery types, measures for evaluation of ED. We chose the Watcha scale because it was reported that this particular scale has a higher overall sensitivity than the other scales used for this purpose [24].

There are a lot of studies showing that pre-school aged children are more prone to emergence delirium occurrence [8,9,24-27], especially boys but our analysis did not show the difference between age or sex groups. The said differences might be due to the chosen different methods in the research. For example, Aono J. et al. in their study followed the exact same procedure in the premedication, induction, and maintenance of anesthesia, including the fact that every patient had been given the same medications and caudal blocks [9]. We, however, recruited patients undergoing more than one type of surgery which is the reason why different protocols in anesthesia were applied. Furthermore, it is not a routine procedure in our hospital to premedicate every patient before anesthesia.

We were looking if preoperative behavior might be somehow linked to ED by measuring the $\mathrm{PAB}$ score during the induction of anesthesia but the results were negative. However, other authors did recognize preoperative anxiety and higher PAB

Table 3. ED between different participant's characteristics.

*ED observed; ** ED not observed.

\begin{tabular}{|c|c|c|c|c|c|}
\hline $\begin{array}{l}\text { Participants' } \\
\text { characterictics }\end{array}$ & ED $(+) *$ n $(\%)$ & ED (-)** n (\%) & p value & df & $\mathbf{X} 2$ \\
\hline Age & $4.79(1-12, \mathrm{SD} 3.22)$ & $5.86(1-12 ; \mathrm{SD} 3.13)$ & 0.134 & & \\
\hline \multicolumn{6}{|l|}{ Age groups } \\
\hline Pre-school & $18(75.0 \%)$ & $66(58.9 \%)$ & \multirow[t]{2}{*}{0.141} & \multirow[t]{2}{*}{1} & \multirow[t]{2}{*}{2.162} \\
\hline School-aged & $6(25.0 \%)$ & $46(41.1 \%)$ & & & \\
\hline \multicolumn{6}{|l|}{ Sex } \\
\hline Girls & $11(45.8 \%)$ & $68(60.7 \%)$ & \multirow[t]{2}{*}{0.533} & \multirow[t]{2}{*}{1} & \multirow[t]{2}{*}{0.352} \\
\hline Boys & $13(54.2 \%)$ & $44(39.3 \%)$ & & & \\
\hline \multicolumn{6}{|l|}{ ASA class } \\
\hline I & $19(79.2 \%)$ & $91(81.2 \%)$ & \multirow[t]{2}{*}{0.055} & \multirow[t]{2}{*}{1} & \multirow[t]{2}{*}{0.814} \\
\hline II & $5(20.8 \%)$ & $21(18.8 \%)$ & & & \\
\hline \multicolumn{6}{|l|}{ Surgery urgency } \\
\hline Urgent & $4(16.7 \%)$ & $14(12.5 \%)$ & \multirow[t]{2}{*}{0.585} & \multirow[t]{2}{*}{1} & \multirow[t]{2}{*}{0.299} \\
\hline Elective & $20(83.3 \%)$ & $98(87.5 \%)$ & & & \\
\hline \multicolumn{6}{|l|}{ Surgery type } \\
\hline General & $15(62.5 \%)$ & $70(62.5 \%)$ & \multirow[t]{3}{*}{0.911} & \multirow[t]{3}{*}{2} & \multirow[t]{3}{*}{0.187} \\
\hline $\begin{array}{l}\text { Orthopedics-Trauma- } \\
\text { tology }\end{array}$ & $5(20.8 \%)$ & $20(17.9 \%)$ & & & \\
\hline Otorhinolaryngology & $4(16.7 \%)$ & $22(19.6 \%)$ & & & \\
\hline
\end{tabular}

Table 4. Relationship between PAB score and ED

*ED observed; **ED not observed.

\begin{tabular}{|l|l|l|l|}
\hline \multicolumn{2}{|c|}{ PAB score } & $\begin{array}{l}\text { ED (+)* } \\
\text { n (\%) }\end{array}$ & $\begin{array}{l}\text { ED (-)** } \\
\text { n (\%) }\end{array}$ \\
\hline 1 & Calm and controlled & $8(33.3 \%)$ & $60(53.6 \%)$ \\
\hline 2 & Tearful but compliant with induction & $9(37.5 \%)$ & $23(20.5 \%)$ \\
\hline 3 & Screaming/shouting, physical resistance to induction & $7(29.2 \%)$ & $29(25.9 \%)$ \\
\hline \multicolumn{2}{|l|}{} \\
\hline $\mathrm{X} 2(\mathrm{df}=2)=4.116 ; p=0.128$ \\
\hline
\end{tabular}


score to be linked with ED $[2,18,28]$. We hypothesize that this difference was impacted by different statistical analysis methods, for example, logistic regression analysis which is a much more complicated test than the ones we have used. There have been some discrepancies in the studies at what time point during the induction the PAB score was measured as we have done that in the time where a patient would lay down on the table and fall asleep. Beringer et al. chose only the time period where anesthetic drugs were administered [21].

In our study, we have found out that a shorter duration of anesthesia is linked to the occurrence of emergence delirium. Voepel-Lewis T. et al. has found out that ED is also linked to otorhinolaryngology surgery which usually doesn't last long in the pediatric population however they did not find that shorter or longer duration of anesthesia might cause ED [3]. On the other hand, they did not specify how long "short" and "long" anesthesia lasted. Other studies show that shorter duration of anesthesia is linked to the occurrence of ED [29]. Some authors report that delay of emergence caused by certain anesthetics is linked with a lower incidence of ED [23]. This indicates that rapid emergence might influence the incidence of this phenomenon of altered state of consciousness. Although shorter anesthesia might be linked with the occurrence of ED there is no way of prolonging anesthesia to avoid ED because that would be unethical and have more risks than benefits.

Table 5. Relationship between VAS score and ED

* ED observed; ** ED not observed.

\begin{tabular}{|l|l|l|l|l|}
\hline Pain management & $\mathbf{N}$ & & ED (+)* & ED (-)** \\
\hline VAS 0-3 & 116 & & $18(15.5 \%)$ & $98(84.5 \%)$ \\
\hline VAS 4-10 & 16 & $6(37.5 \%)$ & $10(62.5 \%)$ \\
\hline & $\mathrm{p}=0.033$ \\
\hline & $\mathrm{X} 2(\mathrm{df}=1)=4.568 ; \mathrm{p}=0.033$ \\
\hline
\end{tabular}

Table 6 . The number of children who experienced ED and changes in post-anesthesia behavior

\begin{tabular}{|l|c|}
\hline Statement & Agreed, $\mathbf{n}$ \\
\hline My child is more anxious & 5 \\
\hline My child is angrier & 2 \\
\hline My child wets the bed more often & 0 \\
\hline My child has lost interest in surroundings & 2 \\
\hline My child bites his/her nails more often & 0 \\
\hline My child gets irritated easier & 3 \\
\hline My child seems to avoid or is afraid of new things & 1 \\
\hline My child has temper tantrums more often & 1 \\
\hline $\begin{array}{l}\text { My child gets upset when someone mentions doctors } \\
\text { or hospitals more often }\end{array}$ & 4 \\
\hline My child is afraid of the dark more than before & 5 \\
\hline
\end{tabular}

Our study also showed that pain and ED might be related. In this case, the PAED scale would be more accurate to distinguish these two states as "No eye contact" and "no awareness of surroundings" identifies ED while "Abnormal facial expression", "crying", and "inconsolability" indicate acute pain in children in the early postoperative period [20]. However, it is possible that children might suffer both from pain and ED at the same time or that pain might cause agitation $[20,30]$. Some studies also show that the incidence of anesthesia emergence delirium was higher in children who had postoperative pain [31]. Other studies describe that patients who experienced ED did not express any pain postoperatively [32]. Nevertheless, it is known that adequate analgesia might prevent ED [33].

We also did not find a link between ED and surgery types even though there are also other studies showing that otorhinolaryngology surgery is a risk factor for ED [32]. This situation might also be linked to various factors such as different protocols of anesthesia applied among hospitals for the same type of surgery or different characteristics in studied populations (age, sex, ASA classes, etc.).

Even though some of the ED experienced children showed signs of post-discharge behavior changes, we cannot really say it is linked to the anesthesia as we were provided only with descriptions of parents' opinions and no reliable statistical tests were applied. Thorough research is needed to investigate this question.

The other limitation of this study might be that all of the children were evaluated not by the same person. The sample was minimal and some of the data was missing. One of the major drawbacks of this study was that multivariate analysis was not applied.

\section{Exceptional cases}

In our opinion, these cases of ED were different from the others. Five years old monozygotic twins were operated for umbilical hernia correction. The sisters weighing 10 and 11 kilograms received the same doses of the drugs during the perioperative period. They both were premedicated with midazolam $0.2 \mathrm{mg} / \mathrm{kg}$. The sisters both scored 3 on the PAB score, experienced agitation after anesthesia requiring treatment with fentanyl. They had the exact same reaction as they both did not maintain any eye contact and cried over 10 minutes. However, the mother of the twins did not notice any kind of change in their behavior on the following 2 weeks after anesthesia. We have failed to find any studies or cases which would describe twins experiencing ED as it is uncommon for both twins to go under the same type of surgery.

One ED case stood out because the agitation after surgery lasted for over 30 minutes while authors of other studies 
propose that ED usually lasts about 5 to 15 minutes [3,34,35]. A 9-year-old boy showed wild thrashing behavior that needed physical restraint, he could not maintain eye contact, screamed and cried all the time. The boy's father said that the patient had 3 surgeries in the past and the postoperative period went well for all of them. He also mentioned that the boy has a high pain threshold, and he would not cry or complain if he felt discomfort or pain until it was very strong. The ED was handled by giving repeated doses of intravenous propofol. However, this prolonged case of ED demanded more personnel in the PACU to care for the boy while ED came to an end. The father of the boy also did not report any change in behavior after surgery. There are some cases that write about long-lasting ED episodes, but they are not that frequent, and it is not known what might impact the duration of ED.

\section{Conclusions}

Even though we have known ED for decades it still remains a mystery. There are some theories on how does it develop but they are still not proven. Researchers disagree on a lot of things concerning this condition. There is no clear definition of this phenomenon. Some opinions on risk factors are unified, some of them are not, just like our study showed that too. The prevalence of ED observed during our study, short duration of anesthesia and postoperative pain association with ED coincided with the results specified by other researchers. ED associated behavior changes were reported in the late postoperative period. Our other findings appeared to be not consistent with the results reported in other studies. Thus, the dilemma of ED still remains unresolved.

Conflicts of Interests: The authors declare no conflict of interest.

\section{References}

1. Malarbi S, Stargatt R, Howard K, Davidson A. Characterizing the behavior of children emerging with delirium from general anesthesia. Pediatric Anesthesia. 2011;21(9):942-950.

2. Wong D, Bailey C. Emergence delirium in children. Anaesthesia. 2015;70(4):383-387. https://doi.org/10.1111/anae.13043

3. Voepel-Lewis T, Malviya S, Tait A. A Prospective Cohort Study of Emergence Agitation in the Pediatric Postanesthesia Care Unit. Anesthesia \& Analgesia. 2003; 96:1625-30. https://doi.org/10.1097/00000539-200302000-00076

4. Hino M, Mihara T, Miyazaki S, Hijikata T, Miwa T, Goto T et al. Development and Validation of a Risk Scale for Emergence Agitation After General Anesthesia in Children. Anesthesia \& Analgesia. 2017;125:550-5.

https://doi.org/10.1111/1471-0528.14826
5. Veyckemans F. Excitation phenomena during sevoflurane anaesthesia in children. Current Opinion in Anaesthesiology. 2001;14:339-43.

6. Beskow A, Westrin P. Sevoflurane causes more postoperative agitation in children than does halothane. Acta Anaesthesiol Scand 1999;43:536-41. https://doi.org/10.1007/BF02463576

7. Uezono S, Goto T, Terui K, et al. Emergence agitation after sevoflurane versus propofol in pediatric patients. Anesth Analg 2000;91:563-6

8. Vlajkovic GP, Sindjelic RP. Emergence delirium in children: many questions, few answers. Anesthesia \& Analgesia. 2007;104:84-91.

9. Aono J, Ueda W, Mamiya K, Takimoto E, Manabe M. Greater Incidence of Delirium during Recovery from Sevoflurane Anesthesia in Preschool Boys. Anesthesiology. 1997;87:1298-1300. https://doi.org/10.1097/00000542-199712000-00006

10. Frederick H, Wofford K, de Lisle Dear G, Schulman S. A Randomized Controlled Trial to Determine the Effect of Depth of Anesthesia on Emergence Agitation in Children. Anesthesia \& Analgesia. 2016;122(4):1141-1146. https://doi.org/10.1213/ANE.0000000000001145

11. Keles S, Kocaturk O. Comparison of oral dexmedetomidine and midazolam for premedication andemergence delirium in children after dental procedures under general anesthesia: a retrospective study. Drug Design, Development and Therapy. 2018; 12:647-653.

12. Dave N. Premedication and induction of anaesthesia in paediatric patients. Indian Journal of Anaesthesia. 2019;63(9):713. https://doi.org/10.4103/ija.IJA_491_19

13. Reduque L, Verghese S. Paediatric emergence delirium. Continuing Education in Anaesthesia Critical Care \& Pain. 2013;13(2):39-41

14. Nasr VG, Hannallah RS. Emergence agitation in children-a view. Middle East J Anesthesiol. 2011;21:175-182.

15. Ringblom J, Wåhlin I, Proczkowska M. A psychometric evaluation of the Pediatric Anesthesia Emergence Delirium scale. Pediatric Anesthesia. 2018;28(4):332-337. https://doi.org/10.1111/pan.13348

16. Kuratani N, Oi Y. Greater incidence of emergence agitation in children after sevoflurane anesthesia as compared with halothane: a meta-analysis of randomized controlled trials. Anesthesiology. 2008;109:225-32. https://doi.org/10.1097/ALN.0b013e31817f5c18

17. Kamienski M, McCartney M, McLaughlin M, Pallaria T. Pediatric Emergence Delirium: A Case Study. Journal of PeriAnesthesia Nursing. 2019;34:469-75. https://doi.org/10.1016/j.jopan.2018.05.011

18. Kain ZN, Caldwell-Andrews A, Maranets I, McClain B, Gaal D, Mayes L et al. Preoperative Anxiety and Emergence Delirium and Postoperative Maladaptive Behaviors. Anesthesia \& Analgesia. 2004;99:1648-54. 
https://doi.org/10.1213/01.ANE.0000136471.36680.97

19. Stargatt R, Davidson AJ, Huang GH, Czarnecki C, Gibson MA, Stewart SA et al. A cohort study of the incidence and risk factors for negative behavior changes in children after general anesthesia. Pediatric Anesthesia 2006;16:846-59.

https://doi.org/10.1111/j.1460-9592.2006.01869.x

20. Somaini M, Engelhardt T, Fumagalli R, Ingelmo P. Emergence delirium or pain after anaesthesia - how to distinguish between the two in young children: a retrospective analysis of observational studies. British Journal of Anaesthesia. 2016;116:377-83. https://doi.org/10.1093/bja/aev552

21. Beringer R, Greenwood R, Kilpatrick N. Development and validation of the Pediatric Anesthesia Behavior score - an objective measure of behavior during induction of anesthesia. Pediatric Anesthesia. 2013;24(2):196-200

https://doi.org/10.1111/pan.12259

22. Charan J, Biswas T. How to calculate sample size for different study designs in medical research? Indian Journal of Psychological Medicine. 2013;35(2):121.

https://doi.org/10.4103/0253-7176.116232

23. Dahmani S, Stany I, Brasher C, Lejeune C, Bruneau B, Wood $\mathrm{C}$ et al. Pharmacological prevention of sevoflurane- and desflurane-related emergence agitation in children: a metaanalysis of published studies. British Journal of Anaesthesia. 2010;104:216-23.

https://doi.org/10.1093/bja/aep376

24. Bajwa SA, Costi D, Cyna AM. A comparison of emergence delirium scales following general anesthesia in children. Paediatric Anaesthesia 2010;20:704-11. https://doi.org/10.1111/j.1460-9592.2010.03328.x

25. Lim B, Lee I, Ahn H, Lee D, Won Y, Kim H et al. Comparison of the incidence of emergence agitation and emergence times between desflurane and sevoflurane anesthesia in children. Medicine. 2016;95:e4927.

https://doi.org/10.1097/MD.0000000000004927

26. Aono J, Ueda W, Mamiya K, Takimoto E, Manabe M. Greater incidence of delirium during recovery from sevoflurane anesthesia in preschool boys. Anesthesiology 1997;87:1298-300. https://doi.org/10.1097/00000542-199712000-00006

27. Aono J, Mamiya K, Manabe M. Preoperative anxiety is associated with a high incidence of problematic behavior on emergence after halothane anesthesia in boys. Acta Anaesthesiol Scand 1999;43:542-4.

https://doi.org/10.1034/j.1399-6576.1999.430509.x

28. Kain ZN, Mayes LC, Caldwell-Andrews AA, Karas DE, McClain BC. Preoperative anxiety, postoperative pain, and behavioral recovery in young children undergoing surgery. Pediatrics 2006;118:651-8. https://doi.org/10.1542/peds.2005-2920

29. Currie P. Understanding and Treating Emergence Delirium [Internet]. University of New England, DUNE: DigitalUNE.
2015 [cited 13 August 2019]. Available from: http://dune.une. edu/cgi/viewcontent.cgi?article $=1003 \&$ context=na_capstones

30. Sikich N, Lerman J. Development and psychometric evaluation of the paediatric anesthesia emergence delirium scale. Anesthesiology. 2004;100:1138-45. https://doi.org/10.1097/00000542-200405000-00015

31. Barreto A, Paschoal A, Farias C, Borges P, Andrade R, de Orange F. Risk factors associated with anesthesia emergence delirium in children undergoing outpatient surgery. Brazilian Journal of Anesthesiology (English Edition). 2018;68:162-7. https://doi.org/10.1016/j.bjane.2017.11.002

32. Wells LT, Rasch DK. Emergence 'delirium' after sevoflurane anesthesia: a paranoid delusion? Anesthesia \& Analgesia. 1999; 88:1308-10. 338

https://doi.org/10.1097/00000539-199906000-00020

33. Dahmani S, Delivet H, Hilly J. Emergence delirium in children. Current Opinion in Anaesthesiology. 2014;27:309-15. https://doi.org/10.1097/ACO.0000000000000076

34. Olympio MA. Postanesthetic delirium: historical perspectives. J Clin Anesth. 1991;3:60-3.

https://doi.org/10.1016/0952-8180(91)90209-6

35. Moore JK, Moore EW, Elliott RA, St Leger AS, Payne K, Kerr J. Propofol and halothane versus sevoflurane in paediatric daycase surgery: induction and recovery characteristics. British Journal of Anaesthesia. 2003;90:461-6.

https://doi.org/10.1093/bja/aeg098

\section{VAIKŲ SUJAUDINIMAS PO \\ BENDROSIOS ANESTEZIJOS}

\section{G. Patapavičiūtè, L. Lukošienè, I. Razlevičè, A. Macas}

Raktažodžiai: sujaudinimas, bendroji anestezija, vaikai.

Santrauka

Sujaudinimas po anestezijos apibūdinamas kaip trumpalaikè kognityvinių funkcijų ir psichomotorinio sujaudinimo būsena, kuri prasideda pasibaigus anestezijai ir tęsiasi ankstyvuoju poanesteziniu laikotarpiu. Sujaudinimo dažnis vaikų populiacijoje svyruoja labai didelèse ribose - nuo 10 iki 80 proc. Patofiziologija ir pagrindiniai mechanizmai nèra tiksliai žinomi.

Tyrimo tikslas: nustatyti sujaudinimo paplitimo dažnį bei galimus rizikos veiksnius vaikams, kuriems buvo atliekama bendroji anestezija.

Metodai. Atliktas perspektyvinis stebimasis tyrimas, ị kurị įtraukti 1-12 metų vaikai. Vaiko elgesys prieš anesteziją buvo įvertintas naudojant vaikų anestezijos elgesio (PAB) skalę. Sujaudinimo vertinimui buvo naudota Watcha skalè, skausmo vertinimui - vizualinè analoginè skalè (VAS). Praejus 2 savaitèms po anestezijos, buvo apklausti pacientų tẻvai dèl galimų vaiko elgesio pokyčių.

Išvados. Tyrimas parode 17,5 proc. ED paplitimą. Trumpa anestezijos trukmė ir pooperacinis skausmas buvo susijęs su sujaudinimo atsiradimu.

Adresas susiršinėti: Laura.Lukosiene@kaunoklinikos.lt

Gauta 2021-06-18 